\title{
Local Language on the News at West Sumatra Print Media
}

\author{
T F Yusandra ${ }^{1}$, A Rahmi ${ }^{2}$, A W Sari ${ }^{3}$, R Yulisna ${ }^{4}$ \\ STKIP PGRI Sumatera Barat \\ \{titiek@stkip-pgri-sumbar.ac.id¹, Afrini@stkip-pgri-sumbar.ac.id², Asri@stkip-pgri-sumbar.ac.id², \\ Risa@stkip-pgri-sumbar.ac.id ${ }^{4}$ \}
}

\begin{abstract}
The tendency of local languages to be used in news content is because of the nuances of meaning that emerge as the effect of using a word. The useing of various regional languages is the desire of the mass media (journalists) to popularize local language terms. In addition, the purpose of using the local languages in the news is to sharpen the meaning of a word, because not all Indonesian languages can represent the meaning of a local language. The purpose of this study is to describe the use of local languages in the news in print media. This type of research is qualitative research with descriptive analysis method. The results of this study indicate that the use of local languages on the news has several objectives, namely as a form of defense and empowerment of local culture. By continuing to insert local language in every published news media, the public will increasingly love the local culture and wisdom (popularizing the term local language in the mass media).
\end{abstract}

Keywords: Local Language, News, Print Media, West Sumatra

\section{INTRODUCTION}

The development of mass media is now a necessity, in supporting various community activities. In this global era, developing technology makes it easier for people to get information quickly and keep up with developments. Mass media, as well as oral and signaling messages have become an integral part of human communication. Technological developments have led to the emergence of various uses of language in accordance with the media used. Information technology is a new chapter in the world order and the development of human communication.

In line with this, the development of technology and science triggers the development of language and mass media. The development of mass media is parallel to language because the language is the main object of mass media. Language, especially diction, is used by the mass media to construct events into news. This topic is interesting to analyze. The jurisdiction is important because it contains a psychological burden behind which can affect the attitude and character of the reader.

The effect can be seen from the public's response to the existence of mass media. Today, mass media is easily accessible to people from various groups. Otherwise, mass media also easily to access for community life into private space. Everything in the mass media is often a reference and way of life for the community. In short, mass media has become a "new teacher" in community life. The existence of mass media is sometimes also able to defeat the existence and popularity of the real teacher.

Mass media is the official channel for disseminating news and messages to the public using language as the main media (KBBI, 2008: 892). This is in accordance with the opinion 
of Widjono (2012: 25) which explains that one of the main functions of language as a means of communication, information transmitter, and means to build intelligence and national character. As a business that is engaged in communication and information services, mass media uses language, especially diction, to develop business.

Each of the diction used by news writers has different objectives. The changes of the concept or the value of the taste occur when a news writer uses the word. For example, when the author conveys the meaning to mention a place that is used by Muslims to worship, the words might be used such as a mosque, "musholla", or "surau". All synonymous words can be chosen to be used in a sentence according to the intent to convey. Each synonymous word is sometimes irreplaceable except in one particular context. This is caused by five factors including, the first factor is time. The use of synonymous words has developed a shift in meaning based on time. The second is place and region. The use of two synonymous words is limited to certain places and regions. Third factos is formality. The use of two synonymous words depends on the level of formality of the situation. Fourth, social factors. The use of two synonymous words is adjusted to the social level. Fifth, activity factors. The use of the same two synonyms depends on the variety of language uses. Sixth, the nuance factor of meaning. The use of two synonymous words cannot be exchanged because they have nuances of meaning (Chaer, 1995).

News writers try to provide in-depth messages from each diction used. So that the written and implied messages can be accept the reader well. One form of diction selection used by news writers in printed newspapers in the city of Padang, West Sumatra, is to use diction in the local language (Minangkabau language). For example is the regional newspapers that tend to use regional language as a way to preserve local wisdom on the West Sumatera. In order for several reasons (1) expanding the meaning, (2) narrowing the meaning, (3) changing the total, (4) smoothing the meaning, (5) targeting the meaning, (6) emphasizing the meaning, and (7) transferring meaning (Manaf, 20018: Keraf, 1996).

The ability to choose attractive words is the key to the success of mass media. Words can influence the behavior, thinking, and orientation of the reader. Therefore, the choice of words is deliberately formulated to suit the needs of the reader, influence the emotions of the reader, and attract readers. Not all meanings of local languages can be represented by Indonesian. This statement is perhaps the reason for the newspapers in West Sumatra to highlight the language of the Minangkabau region. Locality on the news is reflected in several West Sumatra daily newspapers such as the Singgalang Public Daily, Padang Ekspress, Metro Post, and Haluan. The use of various regional languages is the desire of the mass media (journalists) to popularize local language terms. The goal is that the language of the Minangkabau region can develop better and more universally.

In addition, the prominence of regional identity or locality on the content of the news is one of the efforts to convey the values and meanings that the local language has different sense values and meaning values than Indonesian. Local languages have emotional values that can directly affect the reader. The interpretation of the influences of mass media sees the meanings people hold for various words as strongly influenced by their exposure to the content of mass communications. (Itine \& Olusegun, 2015).

For example, in the news column in the "Posmetro newspaper" there are diction with Minangkabau language diction. "Ayah Kebelet saat Antrean BBM, Mobil Disetir ABG Rabah Kudo" (Posmetro, 18 Maret 2019), the news title is one example of the use of regional languages, Rabah Kudo. By this diction, the reader can immediately imagine the car driven by ABG collapsing like a horse. The use of diction is certainly to sharpen the intention in the 
news submitted by journalists. Therefore, the explaining of the using local language on the news in regional newspapers is important.

\section{RESEARCH METHOD}

The type of this research of qualitative research because it not only to examine the pieces of information but examine the connection each information in the news. Qualitative research for journalistic writing begins with selecting news that fits the needs of the study, interpreting the data in depth by showing it in different contexts, and finally reporting it in a different perspective frame according to the subject of the report (Iorio, 2004). The qualitative research methodology for media is research that combines many different paradigms to avoid biased results. Qualitative research for media is a theoretical screening of the concept of reality from realism to relativism. Research on the media tries to explain, predict, and supervise the causal relations between the media and their social societies (Brannen, 2013).

\section{RESULT AND DISCUSION}

The use of the Minangkabau regional language in news writing is one form of defense and empowerment of regional languages conducted by news writers. The use of the Minangkabau language as part of journalistic writing is also used to aim at highlighting more precise intentions, because Indonesian is considered fewer representatives describing the purpose of the news. The use of the Minangkabau language in journalistic writing tries to build meaningful relationships that are in accordance with the context of the Minang community as the news reader.

The relation of meaning in linguistic studies is related to the ability of diction in expressing the meaning desired by the communicant. The word synonym is not necessarily interchangeable to convey an intention. Semantics is the area of linguistics that deals with the study of meaning. The ways in which words and sentences of various grammatical constructions are used and understood by speakers of a given language are explained in semantics. Semantics, therefore, is the science of meaning. Although it deals with the meanings of different words and sentences of various grammatical. (Itine, S., \& Olusegun, O, 2015).

The meaning of two words that are synonymous in two different languages is certainly related to the context of the use of the word. The ability of a word to form a meaning is related to the context in which the word is used. the same words if used in different contexts will give rise to different meanings, moreover the synonymous words are in two different languages, namely Minang and Indonesian (Ozturk, 2017).

The use of the word Surau (Minangkabau language) on the news "The Baiturrahmah Foundation in the City of Padang, in commemoration of its anniversary, handed over a donation of Rp. 50 million, to support the Smart Surau program "for example, synonymous with Mushala (Indonesian) has two different meanings. These differences in meaning are caused by regional factors and the nuances of meaning factors. Judging from regional factors, the word surau for the Minang community has a broader meaning than the place of worship. Surau for the Minang community is a place for all activities related to religion. Among them are recitation, dawn education for children, a place to carry out wirid for teenagers and mothers, a gathering place for Islamic organizations for young people. All activities related to the religious field are generally carried out in surau, except Friday prayers. Friday prayers are usually held in the mosque. The use of the word mushalla is considered to be less 
representative of the intention to be conveyed in the news quote. Furthermore, crew phrases are phrases found in news content using phrases in the Minang language. The word urang means someone or human while the word crew means yourself.

The word urang is often paired with the word crew so that it becomes the urang crew phrase which means indigenous people. The phrase used by the news writer to convey information about the West Sumatra football team, namely Semen Padang was able to reduce the lagging score when competing against the Bali United team.

Another factor that causes the tendency of local languages to be used in the content of the next news is because of the nuances of meaning that emerge as the effect of using a word. Characters contained of the local language is a desire to highlight the elements of regional identity or locality (local wishdom). The desire to accentuate the locality is an effort to convey the others values than the meaning of words from local language. Local language have the value taste and value different meaning than diction of Indonesian language (Delfia, 2017). Although the words surau and the word mushala are the same two synonyms, but these two words cannot be mutually substituted, especially if they are related to the context of the news that will be read by the Minangkabau community. The meaning of the word surau becomes more superficial or experiences a narrowing of meaning when replaced with the word Mushala.

Social factors are also one of the factors found in the news content in the Posmetro Padang newspaper. The word nan tuo which means the old in Indonesian which means people who are old or people who are over 40 years old. The word tuo has synonyms, namely, the word aging But in the news entitled Tempest of the Traders of Bukitiinggi, the word nan tuo is used for female traders who sell in the market of Aua Bukittinggi. The word nan tuo is more appropriate than the old words because the sense values raised from the two synonymous words are very different $[10]$.

Another example of the use of the Minang language in the news is said galodo or in the Indonesian language synonymous with flood. The use of the word galodo is more appropriate to describe the intent that the news writer wants to convey to his readers. This can be seen based on the following factors. First place factor, galodo for the Minang community is a major disaster that is not only limited to the overflow of water as meant by the word flood. Galodo is a disaster that is not only a flood of water but also other disasters caused due to the presence of relatively large amounts of water, for example causing landslides or fallen trees and so forth. The flood for the Minang people is only in the form of water overflowing in the river. But galodo for the Minang community is a natural disaster that can cause various other natural events that are very dangerous.

\section{CONCLUSIONS}

Based on the discussion it can be concluded that the use of local varieties, especially the Minang language on print media published in the Minang area, became a separate strategy for the mass media to attract public reading interest in the published news. The use of the Minang language that is close to people's daily lives makes the results of print media products easier to read and understand. With the use of local languages that are close to the reading community, the purpose of the information in the news that is written is correctly interpreted by the reader. In addition, the use of local varieties in the news is also a form of defense and empowerment of local culture. By continuing to insert local language in every published print media, the public will increasingly love the local culture and wisdom. 


\section{REFERENCES}

[1] Brannen, Bonnie S. 2013. Qualitative Research: Method for Media Studies. New York: Simoultaneously Published.

[2] Chaer, Abdul. 1995. Introduction to Semantic Indonesian Language. Jakarta: Rineka Cipta.

[3] Elina, Etc. 2018. Research on Educational Media: Balancing between Local and Target Language Cultures in English Electronic Textbooks. Tojet jounal V17 issue 2.

[4] Iorio, Sharon Hartia. 2004. Qualitative Research In Journalism .: Taking IT to The Street. NJ: Laurence Elbaraum Associate Inc. Publisher.

[5] Keraf, Gorys. 1996. Language and Language Style. Jakarta: Main Gramedia Library.

[6] Manaf, Ngusman Abdul. 2008. Semantic: Theory and Applied in Indonesian. Padang: Sukabina Offset.

[7] Ozturk, Meral. 2017. Word with multiple meaning in authentic L2 text: An Analysis of "Harry Potter and Philosopher's Stone. Reading Matrix: An International Online Journal v17 n2 p133-141 Sep 2017.

[8] Delfia, E. (2017). Dictionaries of News Headline in West Sumatra Mass Media. Arbitrator Journal, 1, 17-26.

[9] Itine, S., \& Olusegun, O. (2015). RESEARCH PAPERS OF THE SEMANTIC IMPLICATIONS OF MEDIA REPORTS ON By, 5 (1), 35-44.

[10] K. Saddhono and D. Sulaksono, "Indoglish as adaptation of english to Indonesian: change of society in big cities of Indonesia." IOP Conf. Ser.: Ear. and Envi. Sci.. vol. 126 no. 1 IOP Publishing, 2018. 